\title{
E-Worksheet for Science Processing Skills Using Kvisoft Flipbook
}

https://doi.org/10.3991/ijoe.v16i03.12381

\author{
Haryanto, Asrial( $\left.{ }^{\bowtie}\right)$, M. Dwi Wiwik Ernawati \\ Universitas Jambi, Jambi, Indonesia \\ porigih@gmail.com
}

\begin{abstract}
This paper presents research on laboratory-based e-worksheets using Kvisoft Flipbook for science process skills. E-worksheets are made with the stages of development, implementation, and evaluation adopted from branches using 90 samples obtained from purposive sampling techniques. The aim is to look at students' science process skills when learning directly measured student science process skills through observation, which is facilitated by e-worksheets using the kvisoft flipbook and found significant results after using the e-worksheet kvisoft flipbook.
\end{abstract}

Keywords—E-Worksheets, Science Process Skills, Kvisoft Flipbook

\section{Introduction}

Whether a nation is advanced or not can be judged from the educational aspect of its nation's children. One effort to improve the quality of education in Indonesia is to improve the education system [1-2]. Some attempts to improve the quality of education include improvement of facilities and infrastructure, changes in curriculum, teaching and learning processes, improvement of teacher quality, the growth of the assessment system, and other efforts that include the education component [3-4]. The development of science and technology creates a new paradigm in the world of education. This is directly proportional to the effectiveness and efficiency during the learning and learning process. Especially in chemistry subjects, according to [5], most require learning support tools. Most chemical materials require practicum to make students more comfortable to understand the lessons taught. One of them is the subject matter of reaction rates.

Moreover, it is combined with appropriate learning methods such as problem-based learning that requires students to find solutions or answers to problems given during education. Learning resources are all things that can facilitate students in obtaining any information, knowledge, experience, and skills in the teaching and learning process. The use of teaching materials in the learning process has benefits for students, among others, arousing motivation, developing creativity, arousing prior knowledge, encouraging the process of understanding, thinking and logical reasoning, communication and student interaction, and contributing to the development of different skills 
and acquisition of values students, as well as retention of desired knowledge, skills, and attitudes [6].

Therefore, the development of science and technology has led to a process of change in all aspects of life, including the world of education [7-8]. The need for services and opportunities for increased learning for students is a driver of the emergence of educational reform. Therefore, education reform must always be carried out by pursuing a learning process that is in line with the times by utilizing Information and Communication Technology (ICT). The use of information and communication technology in learning can support and develop students' skills, both cognitive, affective, and social skills of students, even higher skills [9] so that the use of information technology in the learning process has become a necessity as well as a necessity. Law of the Republic of Indonesia Number 20 of 2003 concerning the national education system states that the learning process is a process of interaction between students and educators and learning resources in the learning environment. The development of science and technology creates a new paradigm in the world of education [10-11]. Most chemical materials require practicum to make students more comfortable to understand the lessons taught. One of them is the subject matter of reaction rates. Moreover, it is combined with appropriate learning methods such as problem-based learning that requires students to find solutions or answers to problems given during education, one of which uses e-worksheets.

The E-Worksheet is one of the solutions in the enrichment of mastery of the material by students [12-14]. E-worksheets are also a means to help and facilitate teaching and learning activities so that effective interactions between students and teachers will be formed so that they can increase student activities in improving learning outcomes. In the e-worksheet, a breakdown of the material, assignments, and exercises related to the content provided [15]. This effort aims to guide students to carry out various activities required. What's more, now, students are required to be more active in solving different subject matter questions studied [16]. Doing practicum is one of the factors that influence student learning outcomes and plays an essential role in supporting the success of the learning process [18]. On the other hand, [19] states that practicum can study material based on direct observation of the symptoms and scientific methods.

Worksheets that have been used in the study of chemistry in the reaction rate material are work forms printed form. Teaching material like this is not optimized to meet the needs of students. Printed worksheets tend to be informative and unattractive that cannot display, sound, video, animation, and images that can provide a clear explanation of the concept being conveyed. In the current technological development, most students are more interested in teaching materials that utilize other media such as computers/laptops, even smartphones, compared to teaching materials in the form of printed worksheets [20]. Therefore, it is necessary to modify the print worksheet in the way of e-worksheets using one ICT product in the form of software or programs. Also, the use of e-worksheets have the potential to change students' views to read and consume interactively and make it comfortable, where printed e-worksheets have images, narratives, and graphics. Still, e-worksheets can contain various features such as audio, music, animation, and video [21]. One of the software used in converting print worksheets in the form of e-worksheets in the form of a flipbook is the maker of 
the Kvisoft flipbook. Flipbook maker software application is one of the apps that support it as a learning medium that will help in the learning process because this application is not only fixated on writing, but can be included in the animated motion, video, and audio that can make interactive learning media enjoyable, so learning becomes not monotonous [22].

Therefore, this study aims to develop student activity sheets in the form of eworksheets using the Kvisoft Flipbook application and know the ability of students' science processes in learning chemistry at the rate of reaction.

\section{Methodology}

There are three stages [22] in this research model, namely (1) Development, (2) Implementation, (3) Evaluation, which will be explained in more detail as follows:

- At the development stage: The student activity sheet on the available reaction rate material is then made into a Kvisoft-based software design rule. The e-worksheet development is validated by experts to test the validity of the product, and the final result of the e-worksheet development process is the e-worksheet design that will be implemented in the next process.

- At the implementation stage: e-worksheets using the kvisoft application prepared are implemented simultaneously with its role and function as e-learning that can facilitate the chemical learning in the reaction rate material in the hope that the system user can use it well and can increase students' understanding of the material reaction rate will be delivered. Also, the use of Kvisoft-based e-worksheets can make it easier for students to use mobile-based and can be carried anywhere without having to bring printed student worksheets. The final result of the implementation process is solving problems in chemistry learning on the reaction rate material using student worksheets with the Kvisoft application that can help the learning process for students.

- In the evaluation phase: The process carried out is to look at the science process skills of students in the use of e-worksheets using the Kvisoft application using observation sheets

In this study, there is content validity carried out in consultation with experts (Expert Validation Evaluation Criteria) under their fields. The validity test in this study involved media experts. The legality of the content can be seen from the suitability of the product with the demands of the curriculum [23]. With the evaluation criteria as in table 1 below. 
Table 1. Validation criteria

\begin{tabular}{|c|l|}
\hline Interval & \\
\hline $0.0-25.0$ & Very Inadequate \\
\hline $25.1-50.0$ & Not Feasible \\
\hline $50.1-75.0$ & Worthy \\
\hline $75.1-100.0$ & Very Decent \\
\hline
\end{tabular}

Construct validity, regarding the construct or structure and psychological characteristics of the aspects to be measured by the instrument. Does the construct explain differences in individual activities or behavior concerning the element being measured. The sample used in this study was 90 students who were obtained by using a purposive sampling technique. Purposive sampling is to choose an example based on specific criteria [24]. In this case, the school criteria used are nationally accredited A. Data collection procedures for referral [25], described in the figure below:

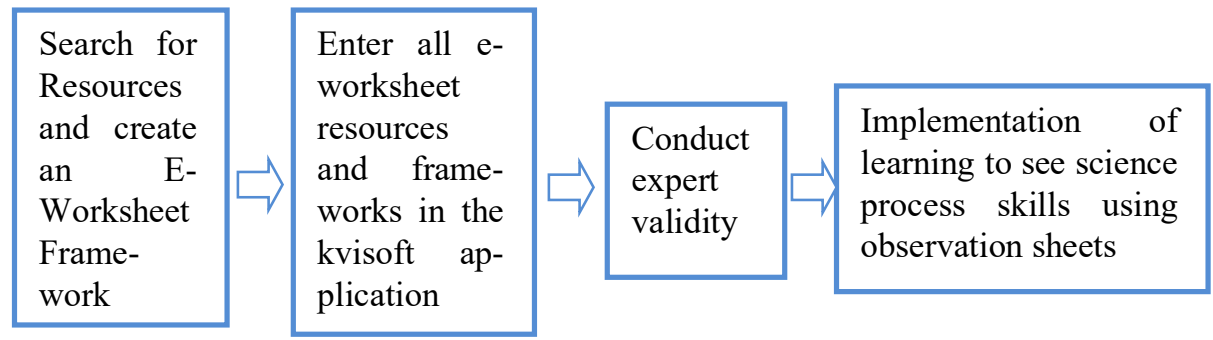

Fig. 1. Data Collection

Based on the picture above, it can be seen that the first activity that must be carried out in the process of data collection, namely creating an e-worksheet and resources framework, then inserting all the resources and e-worksheet structures in the kvisoft application, after completing the kvisoft form, a validation test is carried out by experts to see the feasibility of e-worksheets after the expert validity test is completed. The results are applied in learning to see students' science process skills in the reaction rate material using observation sheets that have been made using a 4 (four) Likert scale for positive statements Very Poor has a score of 1 , Not good to have a score of 2, Good to have a score of 3 and Very Good for 4. For negative statements Very good to have a score of 4 , Not good to have a score of 3 , good to have a score of 2 , and Very good to have scored 1 . And the categories can be seen in table 2.

Table 2. Category Science Process Student Skills

\begin{tabular}{|c|l|}
\hline Interval & \\
\hline $0.0-25.0$ & Very Not Good \\
\hline $25.1-50.0$ & Not Good \\
\hline $50.1-75.0$ & Good \\
\hline $75.1-100.0$ & Very Good \\
\hline
\end{tabular}


Data obtained through observation sheets were analyzed using inferential statistics with a t-test (Independent sample t-test) with the help of the SPSS 21 computer program. While perception questionnaire data were analyzed using descriptive statistics assisted by SPSS 21 computer program.

\section{$3 \quad$ Results and Discuss}

The results of the study conducted by this researcher are modifications to the activity sheet based on science process skills on the reaction rate material using the kvisoft flipbook application. In Indonesia, especially in the learning activities carried out, usually using printed activity sheets. Therefore, the researchers made an innovation by making electronic activity sheets based on Kvisoft's flip-book books that were used with students who were studying reaction rate material. Therefore, the renewal in this study is the change of printed teaching materials into Kvisoft flipbook-based electronics. This e-worksheet contains subject matter, work procedures, and assessment formats which are all based on science process skills to be able to train or develop students' science process skills

Learning activities are designed so that students can actively build concepts, laws, or principles through the stages of formulating a problem, making a background, constructing a hypothesis, testing a hypothesis, analyzing data, drawing conclusions, and communicating results. During the learning activities taking place, of course, all students need learning resources as a tool that is used as a source of learning information. Teaching materials have various types consisting of printed and non-printed teaching materials. Printed teaching materials include books, leaflets, and modules.

Along with advances in information technology, teaching materials used in the learning process also develop and innovate for the advancement of education. One of the beneficiaries of information technology in the world of education. The e-Learning process can be defined as a teaching-learning process through support for information and communication technology (ICT) [26]. The use of e-learning as a teaching and learning tool is now rapidly developing into education, with thousands of courses offered by educational institutions [27]. The school uses information technology as a learning medium and increases the capacity of lecturers and students to improve the quality of education. The types of learning resources that are most commonly used are: E-journals, E-books, E-modules, aggregate text databases, indexing, and abstract databases, reference databases (biographies, dictionaries, directories, encyclopedias), Numerical and statistical database, images, and audio-visual resources [28]. All of these resources are advantages when you come with learning and teaching activities [29].

The use of information technology is one crucial factor that allows the speed of transformation of knowledge to students. Research by utilizing information and communication technology, one of which is the development of printed teaching materials into electronic-based worksheets, better known as e-worksheets.

The final form of e-worksheets using the modified Kvisoft application is as follows. 


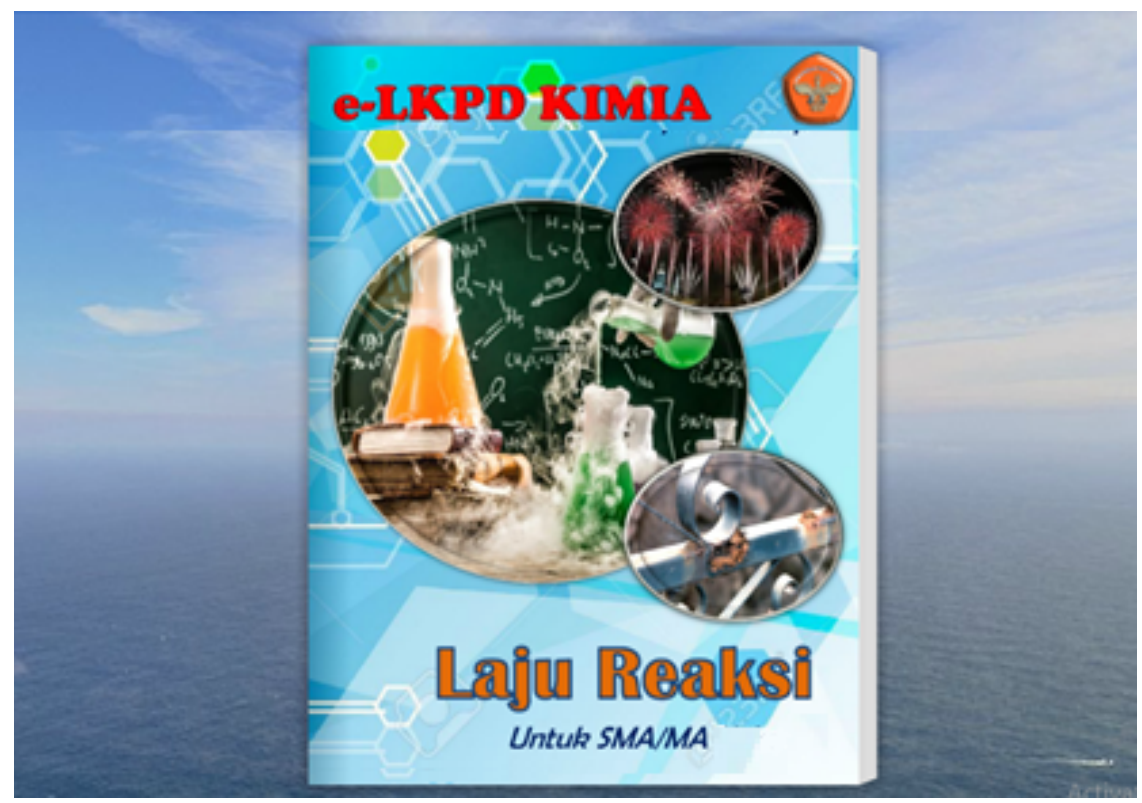

Fig. 2. The first page of the e-worksheet on the reaction rate material

Figure 2 is the starting page of the e-worksheet on the reaction rate material using the Kvisoft Flipbook.

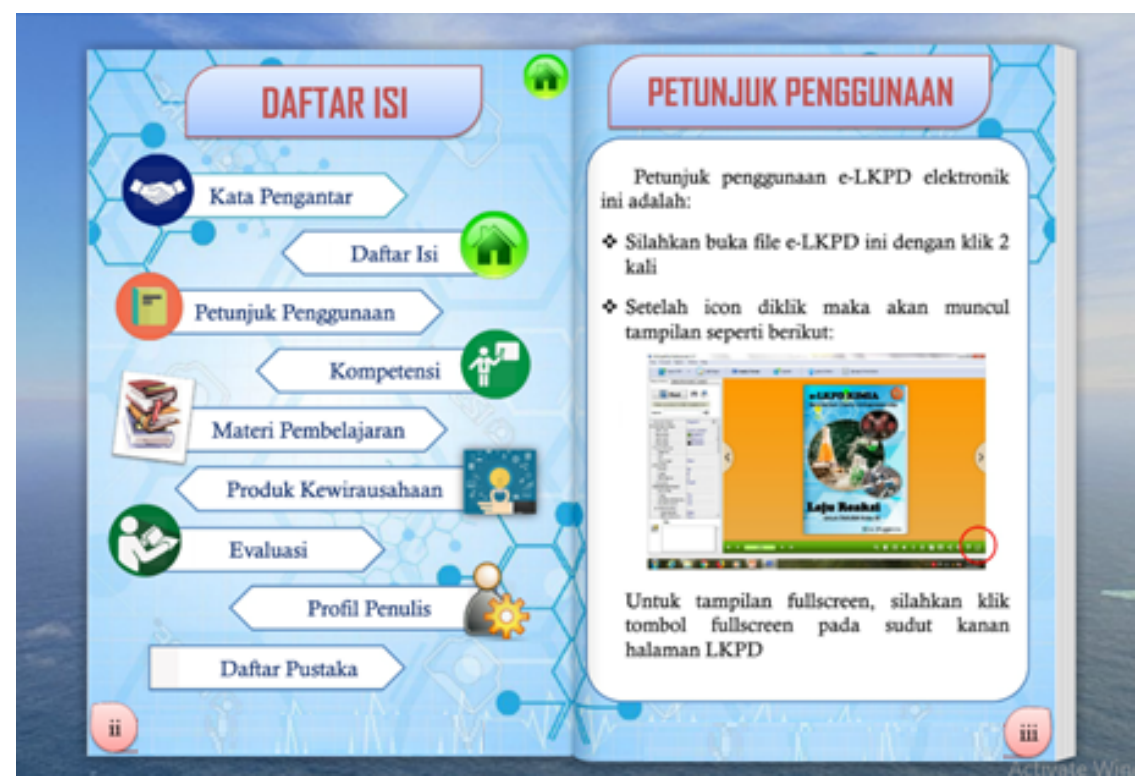

Fig. 3. Table of contents and instructions for using e-worksheet 


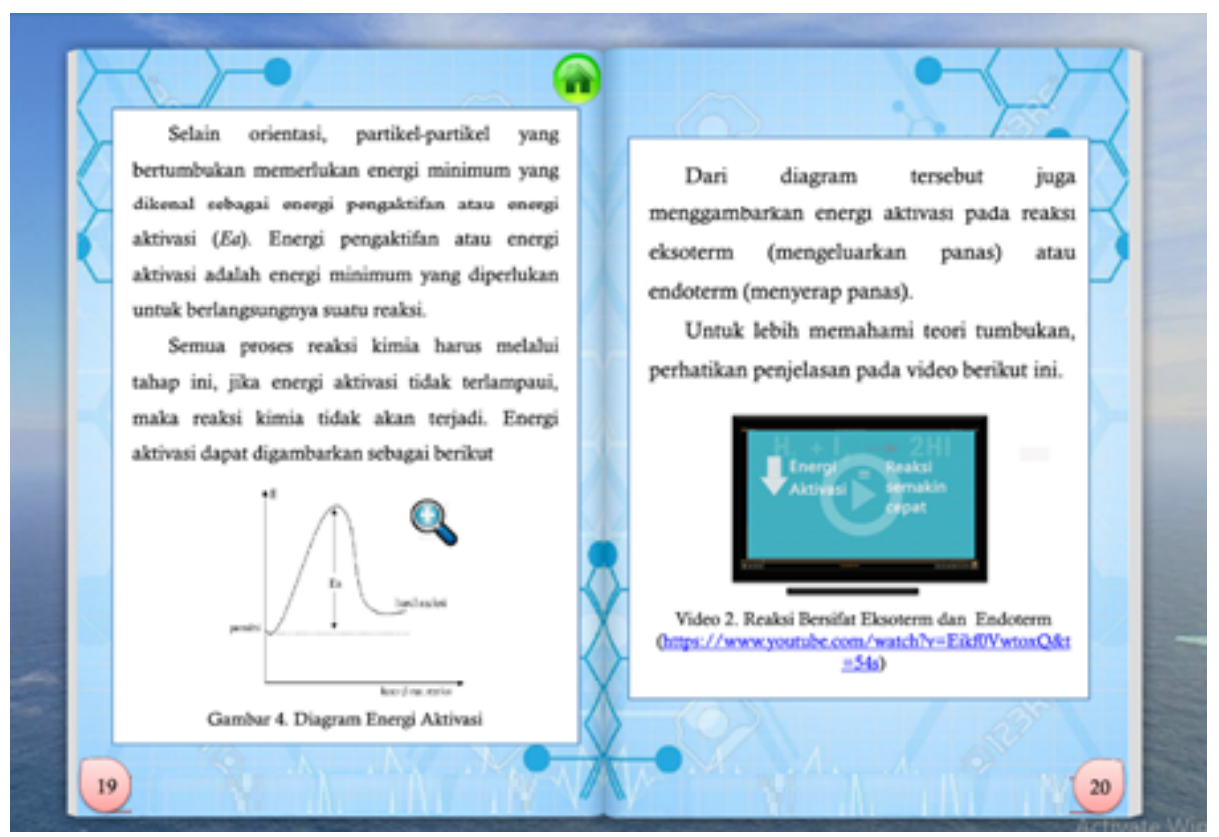

Fig. 4. The material page of the reaction rate

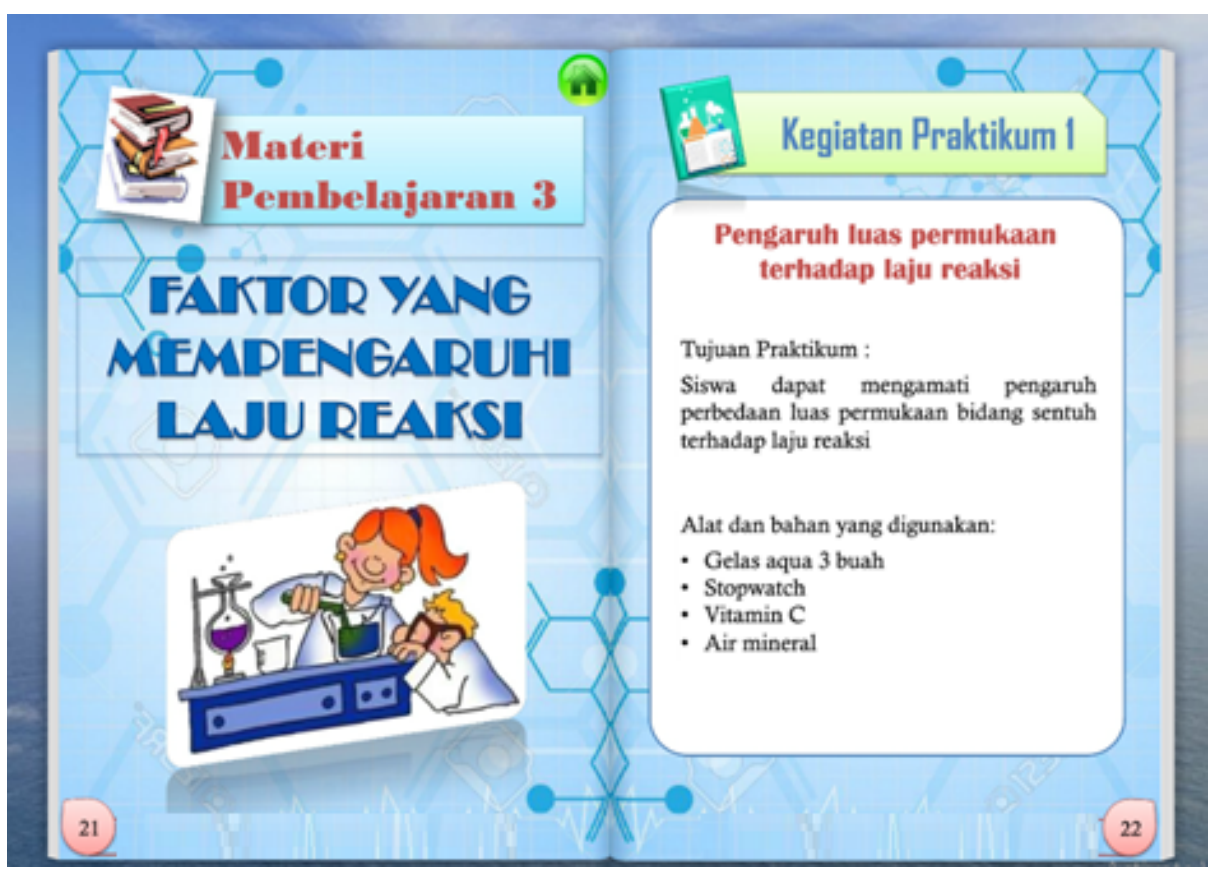

Fig. 5. Practicum Activity page 


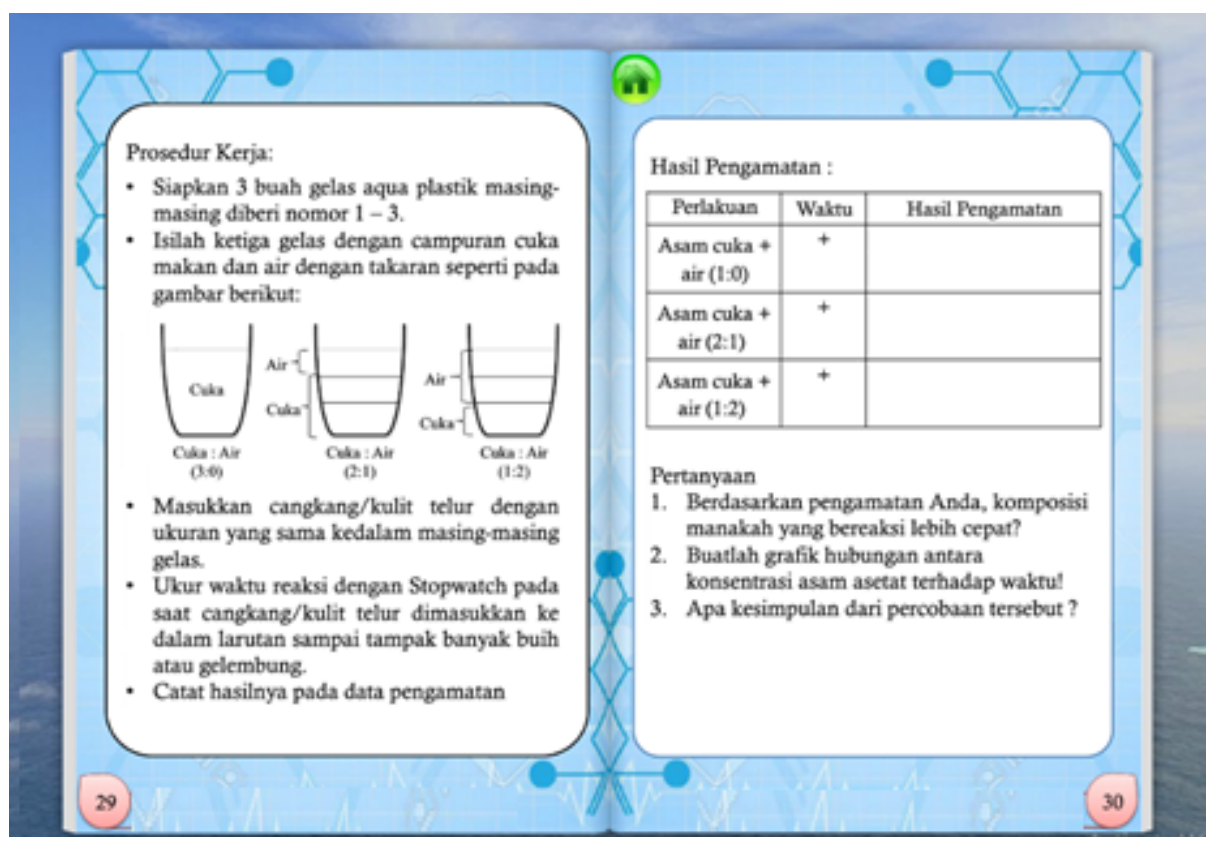

Fig. 6. Work procedures and questions in the practicum

Fig 2-6 is the contents of an e-worksheet of reaction rate material

The activity sheet based on the science process skills supported by the kvisoft flipbook is validated beforehand to the experts. The results can be seen in table 3 .

Table 3. Results of expert validation of e-worksheet

\begin{tabular}{|c|l|c|l|}
\hline No & \multicolumn{1}{|c|}{ Aspect } & Feasibility Level & Category \\
\hline 1 & Theory & 87.3 & \multirow{2}{*}{ Very Decent } \\
\hline 2 & Display & 89.6 & \\
\hline 3 & Language & 88.5 & \\
\hline
\end{tabular}

From the results of the validation carried out by experts, it was found that the very feasible category for the material aspect with a level of eligibility was 87.3 , the display aspect was 89.6 with a very decent category, and the language aspect had a level of eligibility. 88.5, which means it's very feasible. Therefore, based on the results of the validation carried out by experts, it can be concluded that e-worksheets using the Kvisoft Flipbook are very viable and useful to use.

After e-worksheets use the modified Kvisoft application, e-worksheets are implemented in a small group of students in chemistry learning on reaction rate material to see students' science process skills about kvisoft-based e-worksheets. Practical activities are more effective in encouraging students to acquire scientific process skills [30]. The following are the results of students' science process skills analyzed using descriptive statistics shown in table 4. 
Table 4. Table 4. Results of students' science process skills on reaction rate material using a kvisoft flipbook-based e-worksheet

\begin{tabular}{|c|c|c|c|c|}
\hline & Aspect & Score & Category & $\mathbf{N}$ \\
\hline \multirow{6}{*}{ 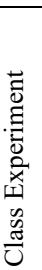 } & Asking Questions or Formulating problems & 88.6 & Very Good & 45 \\
\hline & $\begin{array}{l}\text { Make a research background and make obser- } \\
\text { vations }\end{array}$ & 78.61 & Very Good & 45 \\
\hline & Construct a hypothesis & 83.79 & Very Good & 45 \\
\hline & Test hypotheses through experiments & 70.35 & Good & 45 \\
\hline & Analyze data and make conclusions & 76.87 & Very Good & 45 \\
\hline & Communicating Results & 76.56 & Very Good & 45 \\
\hline \multirow{6}{*}{ 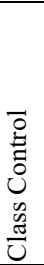 } & Asking Questions or Formulating problems & 74.52 & Good & 45 \\
\hline & $\begin{array}{l}\text { Make a research background and make obser- } \\
\text { vations }\end{array}$ & 73.61 & Good & 45 \\
\hline & Construct a hypothesis & 71.79 & Good & 45 \\
\hline & Test hypotheses through experiments & 70.35 & Good & 45 \\
\hline & Analyze data and make conclusions & 69.87 & Good & 45 \\
\hline & Communicating Results & 72.56 & Good & 45 \\
\hline
\end{tabular}

We can see in table 4, and we get very different results between the control class and the experimental class, this is because the experimental class has used a kvisoft flipbook-based e-worksheet on the reaction rate material. In contrast, in the control class, it uses the usual print activity sheet. From the two classes, we can see that the most dominant aspect is the aspect of making a research background. This is because the element of doing background research or observing the experimental class increases with a perfect level of achievement, while the control class is excellent. The high degree of performance in the experimental class is because, in the e-worksheet, the students are provided with examples of observing steps. This is following the worksheet designed by [31] as a web-based practical, flexible, and educative learning media. This also underlines that the aspect of constructing the hypothesis of the experimental class is higher than that of the control class, this is because the e-worksheet experiment provides indicators in predicting short answers. Science process skills are thought to provide students with meaningful learning experiences because they help students to achieve higher-order thinking and critical thinking [32]. Where critical thinking is the initial foundation for the development of creative thinking [33]. Mastering science process skills enables students to acquire the skills needed to solve everyday problems [34]. Science process skills are thinking skills that are used to process information, solve problems, and form conclusions [35]. Science process skills are the drivers of the discovery and development of facts and concepts, as well as the growth and development of attitudes and values [36]. The importance of mastering science process skills by students can facilitate students in understanding abstract concepts if they learn through concrete objects and are carried out by students themselves through direct learning experiences. Learning through experience can be done directly through practical activities [37]. 
Table 5. Independent sample t-test

\begin{tabular}{|l|c|c|c|c|c|c|}
\hline & & \multirow{2}{*}{$\mathbf{t}$} & \multirow{2}{*}{ df } & \multirow{2}{*}{ Mean } & \multirow{2}{*}{ Std.Deviation } & \multicolumn{2}{|c|}{$\begin{array}{c}\text { 95\% confidence } \\
\text { interval }\end{array}$} \\
\cline { 5 - 7 } & & & & & Lower & Upper \\
\hline $\begin{array}{l}\text { Science Processing Skills } \\
\text { in e-worksheet }\end{array}$ & 16.624 & 90 & 3.0906 & .24321 & 18.234 & .6120 \\
\cline { 2 - 7 } & 16.624 & 98.067 & 2.2033 & .30015 & 17.985 & .8615 \\
\hline
\end{tabular}

From table 5, it can be seen that the value of $t$ is obtained (tcount) with the amount of ttable. t-table values can be found in table 5 statistics at the significance of 0.025 (2-tailed test) with 90 degrees of freedom (df). In this study, the results for the ttable were 1.98525. As for the tcount, it can be seen in Table 5. (Column $t$ ), which is 16.624. The hypothesis testing criteria is that the t-value is higher than the t-value, there is a rejection of $\mathrm{HO}$ [38]. So, it can be concluded that there are significant differences in the mastery of science process skills among chemistry education students who use Kvisoft-based e-worksheets and do not use reaction rate material activity sheets. It can be seen from Table 5 that the average value of students' scientific process skills is 3.0015 , which means that the use of e-worksheets can train students' science process skills.

Based on data obtained from the implementation of e-worksheets based on science process skills, it can be seen that the use of e-worksheets is useful in training students' science process skills. This is based on e-worksheets that are part of e-learning, where the use of e-learning in learning makes the learning process sustainable. Besides that E-learning is a solution in offering a variety of possibilities for social networking so that in this way, the teacher can keep various records of student interactions in collaborative learning [39-41]. And students are motivated to learn in class because of the comfortable laboratory space that makes students excited to go to the laboratory [42]; [43].

\section{Conclusion}

It can be concluded that there is an increase in SPS during the learning process using Kvisoft e-worksheets. Because by using e-worksheets, it is easy for students to learn by using the gadgets they have. Explanations using devices are more precise, more interesting, easy to carry, and they have more preliminary knowledge before learning activities begin. So that lecturers and teaching assistants in the learning activities are more helped to convey information in learning.

\section{Acknowledgement}

Thank you to the principal who allowed me to do research at his school, as well as the class teacher who accompanied me and all students who were willing to be sampled in this study I say thank you. 


\section{$6 \quad$ References}

[1] Asrial., Syahrial., Kurniawan, D. A., Chan, F., Septianingsih, R., Perdana, R. Multimedia Innovation 4.0 in Education: E-Modul Ethnoconstrucivism. Universal Journal of Educational Research. vol. 7, no. 10, pp. 2098-2107. 2019. https://doi.org/10.13189/ujer.2019 .071007

[2] Astalini., Darmaji., Kurniawan, W., Khairul, A., \& Kurniawan, D. A. Effectiveness of Using E-module and E-Assessment. International Journal of Interactive Mobile (IJIM), vol. 13, no. 9, pp. 21-39. 2019. https://doi.org/10.3991/ijim.v13i09.11016

[3] Astalini., Kurniawan, D. A., Sulistiyo, U., Perdana, R., Susbiyanto, S. (2019). EAssessment Motivation in Physics Subjects for Senior High School. International Journal of Online and Biomedical Engineering (iJOE). Vol. 15, no. 9, pp. 4-15. 2019. https://doi. org/10.3991/ijoe.v15i11.10843

[4] Maison., Astalini., Kurniawan, D. A., Perdana, R., Anggraini, L. The Phenomenon of Physicology Senior High School Education: Relationship of Students' Attitudes towards Physics, Learning Style, Motivation. Universal Journal of Educational Research. vol. 7, no. 10, pp. 2199-2207. 2019. https://doi.org/10.13189/ujer.2019.071018

[5] Juwairiyah, J. J. V. J. Alat peraga dan media pembelajaran kimia. Visipena Journal vol. 4, no.1, 2013.

[6] Harrison, F. Using learning resources to enhance teaching and learning. Center For Education Development: London. 2003.

[7] Astalini, Kurniawan, D. A., Perdana, R., \& Kurniawan, W. (2019). Identification Attitudes of Learners on Physics Subjects. EST Journal of Educational Science and Technology, vol. 5, no. 1, pp. 39-48. https://doi.org/10.26858/est.v5i1.8231

[8] Kurniawan, D, A., Astalini., \& Anggraini,L. Evaluasi Sikap SMP Terhadap IPA di Kabupaten Muaro Jambi. Jurnal Ilmiah Didaktika: Media Ilmiah Pendidikan dan Pengajaran. Vol. 19, no. 1, pp. 123-139. 2018. https://doi.org/10.24252/lp.2018v21n2i7

[9] Hidayat, H., Kusumaningrum, I., \& Mardin, A. (2017). Needs Analysis of Entrepreneurship Pedagogy of Technology and Vocational Education with Production Base Learning Approach in Higher Education. International Journal on Advanced Science, Engineering and Information Technology, vol. 7, no. 5, pp. 1701-1707. https://doi.org/10.18517/ijaseit .7 .5 .1510

[10] Asrial., Syahrial., Kurniawan, D. A., Nugroho, P., Perdana, R. Supporting Technology 4.0: Ethoconstructivist Multimedia for Elementary Schools. International Journal of Online and Biomedical Engineering (iJOE), vol. 15, no. 14, pp. 54-66. 2019. https://doi.org/10.3991/ ijoe.v15i14.11365

[11] Chalim, M. A. Pengaruh Perkembangan IPTEK Terhadap Permasalahan HAKI. Jurnal Dinamika Hukum, vol. 11, pp. 47-58. 2011. https://doi.org/10.20884/1.jdh.2011.11.edsus. $\underline{261}$

[12] Bulte, A. M., Westbroek, H. B., de Jong, O., \& Pilot, A. A research approach to designing chemistry education using authentic practices as contexts. International Journal of Science Education, vol. 28, no. 9, pp. 1063-1086. 2006. https://doi.org/10.1080/095006906007 $\underline{02520}$

[13] Choo, S. S., Rotgans, J. I., Yew, E. H., \& Schmidt, H. G. Effect of worksheet scaffolds on student learning in problem-based learning. Advances in health sciences education, vol. 16, no. 4, pp. 517. 2011. https://doi.org/10.1007/s10459-011-9288-1

[14] Hass, M. A. Student-directed learning in the organic chemistry laboratory. Journal of Chemical Education, vol. 77, no.8, pp.1035. 2000. 
[15] Zulkarnain, M., Faiz, A., Hisham, S., Dalila, N., Ismail. E-Logic Trainer Kit: Development of an Electronic Educational Simulator and Quiz Kit for Logic Gate Combinational Circuit by using Arduino as Application. International Journal of Online and Biomedical Engineering (iJOE), vol 15, no. 14, pp. 67-77. 2019. https://doi.org/10.3991/ijoe.v15i14.11410

[16] Tandogan, R. O., \& Orhan, A. The Effects of Problem-Based Active Learning in Science Education on Students' Academic Achievement, Attitude, and Concept Learning. Online Submission, vol. 3, no.1, pp. 71-81. 2007. https://doi.org/10.12973/ejmste/75375

[17] Hascher*, T., Cocard, Y., \& Moser, P. Forget about theory-practice is all? Student teachers' learning in practicum. Teachers and teaching, vol. 10, no. 6,pp. 623-637. 2004. https:// doi.org/10.1080/1354060042000304800

[18] Makarem, S., Dumit, N. Y., Adra, M., \& Kassak, K. Teaching effectiveness and learning outcomes of baccalaureate nursing students in a critical care practicum: a Lebanese experience. Nursing Outlook, 49(1), 43-49. 2001. https://doi.org/10.1067/mno.2001.111186

[19] Irwansyah, F. S., Lubab, I., Farida, I., \& Ramdhani, M. A. (2017, September). Designing an Interactive Electronic Module in Chemistry Lessons. In Journal of Physics: Conference Series (Vol. 895, No. 1, p. 012009). IOP Publishing. 2017. https://doi.org/10.1088/1742-65 $\underline{96 / 895 / 1 / 012009}$

[20] Nindy Apsari, A., \& Kustijono, R. Development Of E-Book Using Kvisoft Flipbook Maker To Train Science Process Skill For Senior High School Students In Curriculum 2013. Inovasi Pendidikan Fisika, 6(3). 2017.

[21] Fonda, A., \& Sumargiyani, S. The Developing Math Electronic Module With Scientific Approach Using Kvisoft Flipbook Maker Pro For Xi Grade Of Senior High School Students. Infinity Journal, 7(2), 109-122. 2018. https://doi.org/10.22460/infinity.v7i2.p109$\underline{122}$

[22] Branch, M, B. Instructional Design: The ADDIE Approach. USA: University Of Georgia. 2009.

[23] Ivers, K. S., \& Barron, A. E. Multimedia Projects in Education: Designing, Producing, and Assessing. USA: Libraries Unlimited. 2002.

[24] Kerlinger, F. N. Foundations of behavioral research. Yogyakarta: Gadjah Mada University Press. 2014.

[25] Cohen, L., Manion, L., \& Morrison, K. Research methods in education. routledge. 2002.

[26] Martínez-Caro, E., Cegarra-Navarro, J. G., \& Cepeda-Carrión, G. An application of the performance-evaluation model for e-learning quality in higher education. Total Quality Management \& Business Excellence, vol. 26, no. 5-6, pp. 632-647. 2015. https://doi.org/ $\underline{10.1080 / 14783363.2013 .867607}$

[27] Anshari, M., Alas, Y., \& Guan, L. S. Developing online learning resources: Big data, social networks, and cloud computing to support pervasive knowledge. Education and Information Technologies, vol. 21, no. 6, pp. 1663-1677. 2016. https://doi.org/10.1007/s106 39-015-9407-3

[28] Darmaji., Kurniawan, D. A., Astalini., Lumbantoruan, A., \& Samosir, S. C. Mobile Learning In Higher Education For The Industrial Evolution 4.0: Perception and Response of Physics Practicum. International Journal of Interactive Mobile (IJIM), vol. 13, no. 9, pp. 420. 2019. https://doi.org/10.3991/ijim.v13i09.10948

[29] Astalini, A., Darmaji, D., Kurniawan, D. A., Melsayanti, R. E-Assessment of Student Perception of Natural Science-Based on Seska in Middle School Students in Indonesia. International Journal of Scientific \& Technology Reseaerch, vol. 8, no. 9, pp. 858-863. 2019.

[30] Noesgaard, S. S., \& Ørngreen, R. The Effectiveness of E-Learning: An Explorative and Integrative Review of the Definitions, Methodologies, and Factors That Promote e-Learning Effectiveness. Electronic Journal of E-learning, vol. 13, no. 4, pp. 278-290. 2015. 
[31] Safriandono, A. N., \& Charis, M. Rancang Bangun E-lembar Kerja Siswa sebagai Media Pembelajaran yang Praktis, Fleksibel dan Edukatif Berbasis Web. Jurnal Tatal, vol. 10, no. 1, pp. 25-35. 2014.

[32] Tilakaratnea, C. TK \& Ekanayakeb, TMSSKY, " Achievement of the science process skills for junior secondary students: based on a sample of grade six and seven students from Sri Lanka," International Journal of Environmental \& Science Education, vol. 12, no. 9, pp. 2089-2108, 2017.

[33] Khoroshikh, P. P., Sergievich, A. A., \& Platonova, R. I. Development of Students' Critical Thinking by Active and Interactive Training Methods. TEM Journal-Technology Education Management Informatics, vol. 7, no. 4, pp. 787-790. 2018.

[34] Kazeni, M. M. M. Development and Validation of a Test Integrated Science Process Skills For the Further Education and Training Learners. (Unpublished Master Thesis), University of Pretoria South Africa. 2005.

[35] Ozgelen, S., Students' science process skills within the cognitive domain framework, Eurasian Journal of Mathematics, Science \& Technology Education, vol. 8, no. 4, pp. 283-292, 2012.

[36] Zeidan, A. H., \&Jayosi, M. R. Science Process Skills and Attitudes toward Science among Palestinian Secondary School Students. World journal of Education, vol. 5, no. 1, pp. 1324. 2015. https://doi.org/10.5430/wje.v5n1p13

[37] Karamustafaoğlu S Improving the Science Process Skills Ability of Science Student Teachers Using I Diagrams. Eurasian J. Phys. Chem. Educ. Vol. 3, no. 1, pp. 26-38. 2011.

[38] Cramer, D., Advanced quantitative data analysis. McGraw-Hill Education (UK). 2003.

[39] Nindy Apsari, A., \& Kustijono, R. Development Of E-Book Using Kvisoft Flipbook Maker To Train Science Process Skill For Senior High School Students In Curriculum 2013. Inovasi Pendidikan Fisika, vol. 6, no. 3. 2017.

[40] Maison, Darmaji, Astalini, Dwi Agus Kurniawan, Peni Sefiah Indrawati. Science Process Skills And Motivation. Humanities \& Social Science Reviews (HSSR), vol. 7, no. 5, pp. 48-56. 2019. https://doi.org/10.18510/hssr.2019.756

[41] Astalini., Kurniawan, D. A., Anggraini, L. Correlation between confidence with attitude toward science in secondary school in Indonesia. Beder Scientific Journal of Education Sciences (BJES), vol. 20, no. 1, pp. 30-45. 2019.

[42] Karyotaki, M., \& Drigas, A. Online, and other ICT Applications for Cognitive Training and Assessment. International Journal of Online and Biomedical Engineering. Vol. 11, no. 2, pp. 36-42. 2015. https://doi.org/10.3991/ijoe.v11i2.4360

[43] Astalini, Kurniawan, D. A., Darmaji, Sholihah, L. R., Perdana, R. (2019).Characteristics Of Students' Attitude To Physics In Muaro Jambi High School. Humanities \& Social Science Reviews (HSSR), vol. 7, no. 2, pp. 91-99. 2019. https://doi.org/10.18510/hssr.2019. $\underline{7210}$

\section{$7 \quad$ Authors}

Haryanto is a lecturer in faculty of teaching and education of Universitas Jambi, Indonesi

Asrial is professor in the study of indigenous knowledge chemical field. This knowledge can be applied to 21 st Century learning at the elementary, junior and senior high school levels. And preparing teacher candidates to understand the value of local wisdom to improve competence pedagogical. By applying education based on 
local wisdom it is hoped that it will be able to create education that gives meaning in the learning process for students. So that education is able to create young generations who are able to preserve and love their own culture. In addition, education must be able to shape human character with high integrity and great character and dignity in accordance with the spirit of education which is humanizing humans. Asrial is the chair of the research group ethnoconstructivism and that group is aimed at analyzing all the values of local wisdom to serve as a medium and source of learning.

M. Dwi Wiwik Ernawati is a lecturer in faculty of teaching and education of Universitas Jambi.

Article submitted 2019-11-15. Resubmitted 2019-12-18. Final acceptance 2019-12-19. Final version published as submitted by the authors. 